\title{
The Influence of Completeness of Facilities, Quality of Service and Competence of Medical Personnel on Patient Satisfaction at the Koeloda Community Health Center, Golewa District, Ngada Regency
}

\author{
Rafael Ocatvianus Byre \\ Maria Helena Carolinda Dua Mea \\ Email: octavianusbyrerafael@gmail.com
}

\begin{abstract}
This study aims to determine (1) To determine the effect of completeness of facilities on patient satisfaction at the Koeloda Health Center. (2) To determine the effect of service quality on patient satisfaction at the Koeloda Health Center. (3) To determine the effect of the competence of medical personnel on patient satisfaction at the Koeloda Health Center. This research includes causality research using a quantitative approach. The sample in this study were 50 patients at the Koeloda Health Center. The data were collected using a questionnaire that has been tested for validity and reliability. Multiple linear regression was used to test the hypothesis of this study. The results of this study indicate that: (1) completeness of the facility has a positive and significant effect on patient satisfaction at the Koeloda Community Health Center, Golewa District, Ngada Regency with a beta $(\beta)$ value of 0.379 (2) the quality of service has a positive and significant effect on patient satisfaction at the Koeloda Health Center, Golewa District Ngada district with a beta value ( $\beta$ ) of 0.461 (3) the competence of medical personnel has a positive and significant effect on patient satisfaction at the Koeloda Community Health Center, Golewa District, Ngada Regency with a beta value $(\beta)$ of 0.887 .
\end{abstract}

Keywords: Completeness of Facilities, Quality of Service, Competence of Medical Personnel, Patient Satisfaction

\section{INTRODUCTION}

Puskesmas Koeloda is one of the services available in Golewa sub-district, Ngada district. With this puskesmas, Golewa people feel happy because the distance from their respective villages to the puskesmas is very close, and easy to reach. However, in the service process in this puskesmas, some patients feel satisfied and some are not satisfied, where the midwives or nurses when giving drugs to their patients only explain when they take the drugs, they do not explain the benefits or uses of the drugs. On a daily basis, the medics only carry out their duties, namely helping patients who are sick, they will also be given days off, namely on Saturdays and Sundays. However, the people's wish is that they want this puskesmas to continue working without any days off, because according to them the illness came suddenly, so the puskesmas must be opened every day. Puskesmas Koeloda has incomplete facilities, and the service process for patients is ineffective, where the employees are less adroit in serving patients. This Puskesmas is not open for up to 24 hours while the wishes of the community are unlimited, as is the lack of relationships between patients and nurses or midwives. Based on the background of the problem, the phenomenon encountered, the researcher conducted a study entitled "The Effect of Completeness of Facilities, Quality of Service and Competence of Medical Personnel on Patient Satisfaction at Koeloda Health Center".

\section{A. Problem Formulation}

1. Is there an effect of completeness of facilities on patient satisfaction at the Koeloda Community Health Center?

2. Is there an effect of service quality on patient satisfaction at the Koeloda Health Center?

3. Does the competence of medical personnel affect patient satisfaction at the Koeloda Health Center?

\section{B. Research Objectives}

In accordance with the problems in this study, the objectives are:

1. To determine the effect of completeness of facilities on patient satisfaction at the Koeloda Health Center.

2. To determine the effect of service quality on patient satisfaction at the Koeloda Health Center. 
3. To determine the effect of the competence of medical personnel on patient satisfaction at the Koeloda Health Center.

\section{Literature Review}

Completeness of health service facilities can be interpreted as a process of cooperation in the utilization of all the completeness of health facilities effectively and efficiently to provide professional services in the field of facilities and infrastructure in an effective and efficient health service process. (Muhammad: 2012). completeness of good facilities is very important in creating customer satisfaction. Clow, et al (2016) stated that service quality is more difficult to evaluate than the quality of goods.

Azrul Azwar in Amalia (2015) defines health service as any effort that is carried out individually or jointly in an organization to maintain and improve health, prevent and treat disease and restore health of individuals, groups or communities. According to Sinambela (2017) the quality of health services is a service activity provided by public service providers who are able to meet expectations, wants and needs and are able to provide satisfaction to the wider community in general and patients in particular. Furthermore, Sinambela (2017: 6) suggests that theoretically, the purpose of public service is basically to satisfy the community.

Fitzimmons in Sinambela (2017: 7) argues that there are five indicators of public services, namely:

1) Reliability, marked by the provision of appropriate and correct services.

2) Tangibles, characterized by adequate provision covering human resources and other resources.

3) Responsiveness, characterized by the desire to serve consumers quickly.

4) Assurance, marked by the level of attention to ethics and morals in providing services.

5) Empathy, marked by the level of willingness to know the wants and needs of consumers

According to Adisasmito (2012) this health service means every effort that is carried out alone or together in an organization to maintain and improve health, prevent and treat disease, and restore health for both individuals, groups and communities.

In this case, Ilyas (2012) argues that to be able to provide excellent service to health services, one of the important components is that knowledge and skills for every health profession must be prime as well. In line with Ilyas, Adisasmito (2012) also argues that one of the factors and indicators of a good health service system is the development of health human resources or health workers.
According to Armstrong (2014) competence is the action dimension of the task, where the action is used by employees to complete their job tasks satisfactorily and what employees provide in different forms and levels of performance. On the other hand, Armstrong (2014) says that competence is a basic characteristic of personnel that is a determining factor for a person's success or failure in doing a job or in certain situations. According to Kotler and Armstrong (2015: 56) consumer satisfaction is a feeling of happiness or disappointment for someone that comes from a comparison between his impression of the performance or results of a product with his expectations. If the reality is more than expected, then the service can be said to be of high quality, whereas if the reality is less than expected, the service is said to be of poor quality. If the reality is the same as the expectation, then the service is called satisfying. Thus service quality can be defined as the distance between the reality and expectations of consumers for the services they receive (Lupiyoadi, 2016). Engel, et al (Tjiptono and Chandra, 2016) stated that customer satisfaction is an after-purchase evaluation where the chosen alternative is at least the same or exceeds customer expectations, while dissatisfaction arises if the results (outcomes) do not meet expectations.

If consumer satisfaction with goods / services is far below what is expected, then consumers will lose interest in producers / service providers, in this case the hospital. Likewise, if the goods / services they enjoy meet / exceed their level of importance, consumers will tend to use the goods / services again (Kotler, and Armstrong 2015).

\section{HYPOTHESIS}

\section{A. Effect of Completeness of Facilities on Patient Satisfaction at Koeloda Health Center.}

Research by Agung, et al (2016) on the influence of nursing service quality, facilities and interest on patient satisfaction in the inpatient room of UIT Makassar Tourism Hospital. This study resulted in the conclusion that the completeness of the facilities has an effect on customer satisfaction. Research by Afriadi, et al. (2016) shows that service quality, price, and completeness of facilities on inpatient satisfaction. The results showed that the facilities had an effect on patient satisfaction. based on the studies that have been described above, the following hypothesis is proposed,

H1: It is suspected that there is a significant influence between the completeness of the facilities on patient satisfaction at the Koeloda Health Center. 
B. Effect of Service Quality on Patient Satisfaction at Koeloda Health Center.

Kosnanil's research (2019) on the effect of service quality on inpatient satisfaction at the Marauke District hospital. This study resulted in the conclusion that service quality has a significant effect on customer satisfaction. Research by Rizky, et al. (2018) on the effect of service quality on inpatient satisfaction at Kediri Leprosy Hospital. This study shows that service quality has an effect on patient satisfaction.

The results showed that service quality had an effect on patient satisfaction. based on the studies that have been described above, the following hypothesis is proposed,

H2: It is suspected that there is a significant influence between service quality on patient satisfaction at the Koeloda Health Center

C. The Effect of Competence of Medical Personnel on Patient Satisfaction at Koeloda Health Center

Faigah A. Badjamal's (2014) research on the effect of competence and facilities on the satisfaction of class 3 inpatients at Palu Hospital. The results of this study indicate that the competence of medical personnel has a significant effect on the satisfaction of class 3 patients at the Palu Regional Hospital. This study shows that the competence of medical personnel has an effect on patient satisfaction.

The results showed that service quality had an effect on patient satisfaction. based on the research that has been described above, the following hypothesis is proposed,

H3: It is suspected that there is a significant influence between the competence of medical personnel on patient satisfaction at the Koeloda Health Center.

\section{METHODOLOGY}

\section{A. Research Design}

The approach in this research is quantitative using surveys and questionnaires as data collection tools. This research describes the conditions seen and encountered in the field regarding a variable, symptom or situation (Arikunto, 2016). This research is an accurate measurement of the phenomena that occur in the community of users. Koeloda Health Center services, Golewa District, Ngada Regency.

\section{B. Population and Sample}

Population according to Arikunto (2016: $108)$ is the whole object of research. The population in this study were all people who used the Koeloda Health Center services, which ended from August to October 2020, as many as 500 people, so that data collection could be done more specifically.

The sample is a population whose characteristics are to be investigated (Sugiyono, 2016). In this study the authors used the Strattafied Sampling sampling method. Where the samples taken are divided into certain levels, such as age, gender, etc. (Sugiyono, 2016). A sample of 50 patients.

\section{DISCUSSION AND RESEARCH RESULTS}

This study aims to determine the effect of completeness of facilities, service quality and competence of medical personnel on patient satisfaction at Puskesmas Koeloda, Ngada Regency. The discussion and results of this research are as follows,

A. Effect of Completeness of Facilities on Patient Satisfaction at Koeloda Health Center, Ngada Regency

The statistical results of the regression test of the facility completeness variable (X1), the tcount value of 2.683 means that tcount $>$ ttable 1.671 and a significant value of $0.002<0.05$, it can be concluded that the hypothesis is accepted and proven. There is a partial and significant effect of the completeness of the facility variable on patient satisfaction. This study shows that the completeness of the facilities has an influence on patient satisfaction of Puekesmas Koeloda, Golewa District, Ende Regency. The results of this study are in line with the research conducted by Agung et al. (2016) on the influence of the quality of nursing services, facilities and interest on patient satisfaction in the inpatient room of the UIT Tourism Hospital in Makassar. This study resulted in the conclusion that the completeness of the facilities has an effect on customer satisfaction. Research by Afriadi, et al. (2016) shows that service quality, price, and completeness of facilities on inpatient satisfaction. The results showed that the completeness of the facilities affect the satisfaction of patients at Puskesam Koeloda, Golewa District, Ngada Regency.

B. The Effect of Service Quality on Patient Satisfaction at Koeloda Health Center, Golewa District, Ngada Regency

The statistical results of the regression test of the service quality variable (X2) on patient satisfaction (Y), the $t$-count value of 3.578 means that tcount $>$ ttable 1.671 and a significant value of $0.001<0.05$, it can be concluded that the hypothesis is accepted and proven. There is a partial and significant influence of service quality variables on patient satisfaction. This study shows that service quality affects patient satisfaction at the 
Koeloda Health Center, Golewa District, Ngada Regency. The results of this study are also in accordance with Kosnanil's (2019) research on the effect of service quality on inpatient satisfaction at the regional hospital in Marauke Regency. This study resulted in the conclusion that service quality has a significant effect on customer satisfaction. Research by Rizky, et al. (2018) on the effect of service quality on inpatient satisfaction at Kediri Leprosy Hospital. This study shows that service quality has an effect on patient satisfaction. The results of this study indicate that the quality of service affects patient satisfaction of Puekesmas Koeloda, Golewa sub-district, Ngada district.

\section{The Influence of Competence of Medical Personnel on Patient Satisfaction at Puskesmas Koeloda, Golewa District, Ngada Regency.}

The statistical results of the regression test of the medical personnel competence variable (X3) on patient satisfaction, the t-count value of 8.895 means that tcount $>$ ttable 1.671 and a significant value of $0.000<0.05$, it can be concluded that the hypothesis is accepted and proven. There is a partial and significant influence of the medical personnel competence variable on patient satisfaction. This study shows that the competence of medical personnel has the ability to increase patient satisfaction at the Koeloda Health Center, Golewa District, Ngada Regency. The results of this study are in line with Faigah A. Badjamal's (2014) research on the effect of competence and facilities on the satisfaction of class 3 inpatients at Palu Hospital. The results of this study indicate that the competence of medical personnel has a significant effect on the satisfaction of class 3 patients at the Palu Regional Hospital. This study shows that the competence of medical personnel has an effect on patient satisfaction. The results of this study indicate that the competence of medical personnel has an effect on patient satisfaction of Pusekemas Koeloda, Golewa District, Ngada Regency.

\section{CONCLUSIONS AND SUGGESTIONS}

The conclusion from the results of the study entitled The Effect of Completeness of Facilities, Quality of Service and Competence of Medical Personnel on Patient Satisfaction at Puskesmas Koeloda, Golewa District, Ngada District are as follows:

1. Completeness of facilities partially and significantly affects patient satisfaction at the Koeloda Community Health Center, Golewa District, Ngada Regency.

2. Service quality partially and significantly affects patient satisfaction at the Koeloda Community Health Center, Golewa District, Ngada Regency.
3. Competence of medical personnel partially and significantly affects patient satisfaction at the Koeloda Community Health Center, Golewa District, Ngada Regency.

Based on the results of the research conducted, the authors provide the following suggestions:

1. Puskesmas Koeloda, to always try to complete the facilities, which in the end is expected to increase patient satisfaction using the services of the Koeloda Community Health Center.

2. Puskesamas Koeloda. in order to always improve services to patients, because this increases the satisfaction of patients who seek treatment at this puskesmas.

3. Puskesmas Koeloda to always improve the competence of medical personnel in terms of training and other activities. This must be done to increase patient satisfaction at this puskesmas.

\section{REFERENCES}

1. Adisasmito, W.2012. Sistem Kesehatan, P.T. Gramedia: Jakarta

2. Afriadi, Yudha., dan Sonang Sitohang. 2016. Pengaruh Kualitas Layanan, Harga, Dan Fasilitas Terhadap Kepuasan Pasien Rawat Inap. Jurnal Ilmu dan Riset Manajemen : Volume 5, Nomor 6.

3. Agung W, Muh., Muzakir., dan Gunawan. 2016. Pengaruh Kualitas Pelayanan Keperawatan, Fasilitas Dan Minat Terhadap Kepuasan Pasien Di Ruang Rawat Inap RSU Wisata UIT Makassar. Jurnal Mirai Management, Volume 1 Nomor 2 .

4. Amalia, L. 2015. Faktor-Faktor Yang Mempengaruhi Ibu Dalam Memilih Penolong Persalinan, Skripsi. Universitas Gorontalo.

5. Amstrong, Michael. 2014. Amstrong'S Handbook Of Performance Management (An Evidence-based guide to delivering high performances) 5th ed. Philadelpia, Kogan Pages Limited.

6. Arif Muhamad. 2012. Pengantar Metodologi Penelitian Untuk Ilmu Kesehatan. UPT Penerbitan dan Percetakan UNS Surakarta

7. Arikunto, S., (2016). Prosedur Penelitian, Suatu Pendekatan Praktek., Jakarta :Rineka Cipta

8. Clow, Keneth E dan Donald Back, 2016. Intgreted Advertising, Prromotion and Marketing Comunication, England : Pearson

9. Ferry Rizki W, Sudjiono dan Mohammad Arifin. 2018. Pengaruh Kualitas Pelayanan Terhadap Kepuasan Pasien Rawat Inap Pada Rumah Sakit Kusta Kediri. JIMEKVolume 1 Nomor 2. E-ISSN :2621-2374

10. Ilyas, Y. 2012. Kinerja, Teori dan Penilaian Penelitian. Pusat Kajian Ekoomi Kesehatan FKM Universitas Indonesia : Jakarta.

11. Kotler Philip and Amstrong, Gary .2015. Dasar-Dasar Pemasaran Jilid 1, Alih Bahasa Benyamin Molan, Prehalindo:Jakarta

12. Kosnani1, Wilhemina .2019. Pengaruh Kualitas Pelayanan Terhadap Kepuasan Pasien Rawat Inap Di rumah Sakit Daerah Kabupaten Marauke, Jurnal Ekonomi, Bisnis dan Akuntansi (JEBA) Volume 21 Nomor 04 Tahun 2019 
13. Lupiyoadi, R. (2016) Manajemen Pemasaran Jasa Berbasis Kompetensi, Salemba Empat : Jakarta.

14. Sinambela, Lijan Poltak, 2017. Manajemen Sumber Daya Manusia, Bumi Aksara : Jakarta.

15. Sugiyono. (2016). Metode Penelitian Bisnis: Pendekatan Kuantitatif, Kulitatif dan R\&D. Bandung: Alfabeta

16. Tjiptono, Fandy dan Gregorius Chandra (2016). Pemasaran Jasa (Prinsip, Penerapan dan Penelitian) Andi :Yogyakarta 